\title{
視聴覚資料組織法
}

—- (5) 視聴覚資料と著作権*—_

\section{How to Organize Audio-Visual Materials in the Health Science Libraries 5. Audio-Visual Materials and Copyright}

\author{
川瀬真** \\ 文化庁文化部著作権課
}

最近における図書館と著作権の係りの深さは，図書 館が情報提供機関であることを考えるとむしろ当然の ことに思えます。以前の図書館は, 情報ソースも書籍, 雑誌が中心であり，またその提供方法も閲覧が中心で あったことから，あまり著作権の問題にとらわれず業 務を行うことができました。しかし, 情報の提供方法 が様変りした今日, 種々の著作権問題が生じてきてい ます。一番大きな問題としては, 複写の問題がありま す。著作権法では, 公共図書館, 大学図書館等一定の 図書館において，一定の条件の下に当該図書館の資料 を用いた複製（複写）サービスを認めています。この 規定は, 複写機器の開発普及を考慮し, 公共的な機能 を果たす図書館が複製（写）物による情報提供を円滑 に行えるよう設けられたものであります。この規定の 創設により，図書館の情報提供機能はある意味におい て充実強化されたわけですが, 反面, 権利者と利用者 との間に立つ図書館は，この規定の運用について大き な責任を負うことになりました。つまり，権利者の許 諾を得る必要がある複写物の作成とそうでないものと の区別を日常業務における具体的な事例に則して判断 する必要性が生じたわけです。更に最近では，この問 題に加えて, 録音物やビデオの貸出し, コンピュータ・ プログラム，データベースなど罒書館を取りまく問題
は多様化してきており，このような問題についても図 書館業務を円滑に行うためには関心を持たざるをえな くなってきています。

このように様々な問題がある中で，本稿では視聴覚 資料に係る問題を中心に取りあげていきたいと思いま す。視聴覚資料は, 最近におけるVTRなどの視聴覚機 器の普及に伴い，図書館においても急速に充実されつ つありますが, これに伴い情報ソースとしての視聴覚 資料の重要性は高まりつつあるとい之ます。もちろん, このような資料の多くは, 映画, 写真などの著作物や, 実演, レコードなど現在著作隣接権で保護されている ものが使われています。したがって，これらを複製等 の方法により利用する場合, 著作権法上注意しなけれ ばならないことがたくさんあります。

説明に当たっては, 読者が理解しやすいように Q \& Aの形式で進めていきたいと思いますが，設問に入る 前に次のことに注意しておいて下さい。

著作権法は, 小説, 映画, 写真などの著作物の著作 者に著作権を付与すると伴に, 著作物の伝達に重要な 役割を果している実演家，レコード製作者そして放送 事業者に著作隣接権を付与しています。この著作権及 び著作隣接権は排他的権利であり, 利用者が著作物又 は実演等をこれらの権利が及ぶ形で利用する場合，権
既報の 4 編は以下のとおり

(1) ビデオカセット編, 医学図書館, 31(3):259-272, 1984.

(2) 録音資料編, 医学図書館, 31(4):371-385, 1984.

*本稿は関東地区医学図書館協議会目録標準化を検討する会 AV 分科会から文化庁の川瀬先生にお願いして,ご執筆いただいたものです。

* * Makoto KAWASE : Copyright Division Cultural Department Agency for Cultural Affairs, 2-2 Kasumigaseki 3-chome, Chiyoda-ku, Tokyo 100, Japan.
（3）静止画像編，医学図書館，32(1)：64-78，1985.

(4) 映画フイルム編, 医学図書館, 32(2)：192-196, 1985 
利者の許諾が必要です。しかし，著作物又は実演等の 利用であれば全く許諾を得る必要があるかというと必 ずしもそうではなく，一定の要件を満たしていれば自 由に使うことができます。

具体的には，まず(1)我が国で保護義務のない著作物 又は実演等は自由に使うことができます。例えば，著 作権条約（ベルヌ条約，万国著作権条約）に加盟して いない中国，韓国などの著作物がこれに該当します。 また，(2)保護期間(著作権一著作者の生存間及び死後 50 年 (原則的保護期間), 著作隣接権一実演, レコー ドの固定，放送後 20 年）が切れた著作物又は実演等も 同様です。更に(3)(1)及び(2)に該当せず，我が国の著作 権法で保護されるものであっても，私的使用のための 複製（30条），図書館等における複製（31条），営利を 目的としない上演等（35条）など著作権法に定めてあ る一定の場合に該当すれば，一定の枠内で著作物又は 実演等を自由に利用することができます。このように 著作物又は実演等を利用する場合は，この(1)，(2)及び (3)に該当し自由利用できるかどうかをよく調べてみる 必要があります。

許諾を求めるのは著作権者又は著作隣接権者です が, これらの権利は財産権ですから譲渡, 相続等によ り著作者以外の者に権利が移転している場合があるの で注意を要します。また，音楽などの分野では，権利 の移転又は権利行使の委任を受けて権利を管理してい る団体（例之ば, (社)日本音楽著作権協会) があるので, そのような場合はこれらの団体から許諾を得ることに なります。

Q 1 テレビ医学講座などの放送番組を図書館所有の VTR で録画し，来館者に利用させることはでき ますか。

A 著作権法では，図書館の公益的な機能に鑑み，時 に規定（31条）を設け，政令で定められた一定の図 書館（大学図書館，公共図書館など）が行う複製を 一定の厳格な要件の下に認めています。ただし，こ の規定の適用は, 図書館が管理している図書, 記録 その他の資料を用いた複製に限定されているので，
この設問の場合はそもそもこの規定には該当しませ ん。また，このようなことを認める他の規定もない ので，権利者の許諾なしにはできないことになりま す。

誰に許諾を求めるかを判断する際は, 著作権と著 作隣接権の問題を分けて考える必要があります。

まず著作権の問題ですが，放送された番組が生放 送によるものではなく，事前に撮影，編集されたビ デオなどの固定物を用いて行われていれば，映画の 著作物と考之られます ( 2 条 3 項)。テレビ医学講座 のような番組は，事前にビデオなどの固定物を作成 しておくのが一般的だと考えられるので，これにつ いての著作権処理が必要となります。この著作権(複 製権）は，通常映画製作者（会社）がもっていると 考之られます。会社の従業員が職務上製作した映画 であり，かつ当該会社名義で公表されていれば，ほ とんどの場合当該会社が著作者であり著作権者で す。(15条) また，フリーの監督などと契約して映画 を製作してもらったとしても，会社は著作者にはな れませんが，映画の著作権の帰属に関寸る特例（29 条）により，当該会社は著作権を有することになり ます。(放送局が放送のための技術的手段として製作 する映画については, 全ての権利が放送局に帰属す るわけではないが，少なくとも複製権は放送局に帰 属しているといえる)

なお，著作権については，このほか例えば映画に 音楽が使われていれば，作詩家又は作曲家の著作権 が，フリーの脚本家の脚本が使われていればその人 の著作権が映画の著作権とは別に働くことになりま すので，これらの処理も必要になります。(28条)

次に著作隣接権の問題ですが, 放送局は, 放送に 係る音又は影像を録音し，録画し，又は写真的複製 する権利（98条）を有しているので，番組録画につ いては放送局の許諾が必要です。なお，放送を受信 して行う有線放送から録画する場合にもこの権利は 働きます。また，東京のキー局から番組分配を受け て地方のネット局が放送する場合については, 東京 のキ一局の許諾が必要なのではなく, 実際に放送電 波を発出したネット局の許諾が必要なことに注意し 
て下さい。

このほか，放送番組にレコードが使われている場 合，レコード製作者の複製権（98条）が働くことに なります。更に番組に俳優などの実演家が出演して いる場合，場合によっては実演家の録音·録画権 $(91$ 条）が働くことになります。

このように，放送番組の複製については，いろん な権利者の権利が働くことになり，利用者の著作権 処理を複雑にしています。しかし, 歌謡番組や劇番 組などはともかくとして, 医学講座のような番組は 処理すべき権利もそう多くないはずですから比較的 簡単に処理できる可能性があります。

Q 2 図書館所蔵のビデオテープ (3/4インチ)を利用 者の求めに応じ $1 / 2$ インチのビデオテープに複製 して提供することはできますか。

A 先述したように著作権法は，大学図書館などの政 令で定められた図書館が行う複製物の作成を一定の 厳格な要件の下に認めています。(31条) この規定の 第 1 号は，一般的に図書館の複写サービスを認めた 規定といわれていますが，もちろん正確には文献複 写に限らず，例之ば録音テープなどの視聴覚資料の 複製も含む規定です。

したがって，ビデオテープについてもこの規定の 適用があるわけですが，複製できるのは原則として 「公表された著作物の一部分」(解釈としては半分以 下）に限られています。視聴覚資料の場合，一部分 を複製しても余り意味がないでしょうから，実質的 には権利者の許諾なしには利用者のために複製する ことができないと考えた方がよいでしょう。

なお，ビデオテープのほとんどは映画の著作物の 複製物と考えられますので, 複製物の作成ではなく, 提供という面からも問題があります。すなわち，映 画の著作者及び映画に利用されている脚本, 音楽な どの著作者は領布権（26条）を有していますので, 映画の複製物を公衆（不特定又は特定多数）に譲渡 (提供)する場合はこの権利が働くことになります。 （有償，無償を問わない）
Q 3 購入した語学などのカセットテープ, ビデオ テープなどの視聴覚資料を貸し出す場合, 著作権 法上どのような問題がありますか。

A この問題についても著作権と著作隣接権の問題を 分けて考える必要があります。

まず, 著作権の問題ですが, 著作権法では映画の 著作物については領布権（26条）を, その他の著作 物については貸与権（26条の 2$)$ を認めており, 著 作物の公衆への貸与行為について権利が㗢くことに なっています。

一方，著作隣接権については，レコード製作者は 自己のレコード（音盤，テープなどの支持物に音を 固定したもの）を利用して作られた商業用レコード （市販の目的をもって製作されるレコードの複製 物）の公衆への貸与について，当該レコードが最初 に市販された日から起算して 1 年間に限り貸与権 を，また当該期間後は相当な額の報酬を受ける権利 を有しています。(97条の 2$)$ 更に実演家についても， 自己の実演が録音されている商業用レコードの公衆 への貸与行為について，レコード製作者の場合と同 様の権利を有しています。(95条の 2 )

このように録音テープやビデオテープの貸出しに ついては，原則的には著作権が㗢くわけですが，も ちろんどのような場合にでも権利が働くわけではあ りません。公益上の理由から次の場合には, 権利が 㗢かないことになっています。

まず，映画の著作物 (映画に利用されている脚本, 音楽などの著作物を含む）については，営利を目的 としていない視聴覚施設（国又は地方公共団体が設 置する視聴覚教育施設, 図書館法第 2 条第 1 項の図 書館など）における無償の貸与を認めています。（た だし，貸与した場合には権利者に相当な額の補償金 を支払わなければならない）(38条4 項)そして，そ の他の著作物については，非営利かつ無料の貸与を 認めています。(38条 3 項) このことは著作隣接権に ついても準用していますので，例えば語学の録音 テープを非営利かつ無料で貸し出したとしても，著 作権はもちろんのこと著作隣接権についても権利が 
働かないことになります。(102条)

図書館における貸与は，ほとんどの場合，非営利 かつ無料と考えられるので, 語学テープなどの録音 物についてはあまり問題がないと思います。問題な のはビデオテープの貸与ですが, 大学図書館は先述 の施設には該当しないので権利者の許諾が必要とい うことになります。ただし，例之ば医学図書館で貸 し出されるビデオテープは, 通常娛楽用の映画など ではなく，医学教育のために作られたものでしょう から著作権の処理はあまり複雑にはならないでしょ う。もちろん貸出しについて権利処理済みのものを 購入すれば何ら問題はありません。

Q 4 語学などのカセットテープ, ビデオテープなど の視聴覚資料は, 誤って消磁されるなどの危険性 があるので購入時に図書館で複製し，オリジナル テープをマスターテープとして保存しておくこと はできますか。

A 著作権法31条 2 号は, 「図書館資料の保存のため必 要がある場合」について政令で定められた図書館が 行う複製を認めています。この資料保存の必要性と いうのは, この規定が権利者の権利行使を制限して いる規定であることから，きわめて厳しい判断規準 が課せられていると考えられています。例えば，書 籍の場合, 欠損・污損部分の補完, 損傷しやすい古 書・稀散本の保存など真にやむをえない場合に限ら れると解されています。視聴覚資料の場合について も書籍の場合と同様に考之るべきです。したがって, 例えば館内利用又は貸出しを目的として, 購入した 視聴覚資料を購入した時点で複製することは原則と して権利者の許諾なしには認められないと解すべき でしょう。資料が高価であるとか入手まで時間がか かるといったことも原則として理由になりません。

Q 5 今度自館で映画（ビデオ）を作るのですが，そ の際 BGM として音楽を使いたいと考えていま す。具体的にはどのような手続をすればよいので すか。
A 我が国には, 著作権に関スル仲介業務二関スル法 律というのがあります。この法律は, 他人の著作権 を管理し利用者に許諾を与える業務を規制していま す。現在，小説，脚本及び音楽の分野について規制 が及んでおり，音楽の分野については社団法人日本 音楽著作権協会 (通称 JASRAC) が文化庁長官から 業務許可を得, 活動を行っています。この団体は国 内の作詩家, 作曲家のほとんどから著作権の移転 (信 託）を受け管理しており，また世界43ケ国の音楽著 作権管理団体66と契約を結んで外国の著作権をも管 理しています。したがって，音楽を使う場合のほと んどは, この団体と契約すれば著作権の処理ができ ることになっています。使用料の額については, JASRACの使用料規定を最後に揭載しておきます。 (但し, 外国曲のビデオ録音についてはこの規定の料 金が適用されないことがあります)

なお，例えば市販されているレコードから音を録 音する場合はレコード製作者や実演家の権利が働く ことになるので注意を要します。この場合, 我が国 はまだ隣接権条約（正式には，実演家，レコード製 作者及び放送事業者の保護に関する条約）に加入し ていないので, 外国原盤のレコード（当該レコード に固定されている実演を含む) の複製は原則として 自由にできます。(但し我が国のレコード保護条約 （正式には許諾を得ないレコードの複製からのレ コード製作者の保護に関する条約）に加入している 関係上，領布（公衆へ譲渡又は貸与）目的の複製に ついては外国のレコード製作者の権利が及ぶことに なります)

参考 1 仲介業務法に基づき業務許可を得ている団 体は次のとおりです。

音楽一社)日本音楽著作権協会 東京都港区西新橋 $1-7-13$

Tel 03-502-6551

放送脚本一脇日本放送作家組合 東京都港区六本木 $2-5$ 八ラビル内 Tel $\quad 03-404-6761$ 
文芸作品一社)日本文芸著作権保護同盟

東京都千代田区紀尾井町 3-23

文藝春秋ビル Tel 03-265-9658

参考 2 (社)日本音楽著作権協会使用料規程（抜粋）

\section{第 9 節 ビデオグラム}

1 録 音

ビデオテープ，ビデオディスク等音と影像を連続し て固定するもの（第 4 節 映画の規定が適用される場 合を除く。以下ビデオグラムという。)に著作物を使用 する場合の著作物 1 曲の使用料は，次によって算出す る。

（1）市販用ビデオグラム

ビデオグラムに著作物を使用する場合の著作物 1 曲の使用料は，次の基本使用料と複製使用料を合計 した額とする。

ただし，既に映画録音の許諾を得て製作され公表 されているものを複製するビデオグラムに著作物を 使用する場合は，複製使用料のみを適用する。

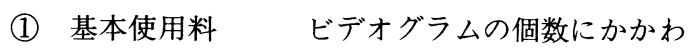
らず，当該著作物の使用時間 1 分までごとに 800 円とする。

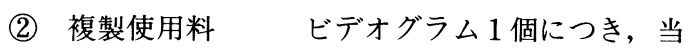
該著作物の使用時間 1 分まで ごとに，次の算式によって算 出した額又は 4 円のいずれか 多い額とする。

\footnotetext{
$\begin{aligned} & \text { 当該ビデオグラムの小売価格 } \\ & \text { (物品税を控除したもの) }\end{aligned} \times \frac{4.5}{100} \times$ $\frac{1}{\text { 総再生時間 }(\text { 註 } 1)} \times \frac{\text { 著作物の合計使用時間 }(\text { 註 } 2)}{\text { 作物の累計使用時間 }(\text { 註 } 3)}$
}

（註 1 ）「総再生時間」とは，当該ビデオグラム の再生に要する時間 (1 分未満を切上 げ）をいう。

（註 2 ）「著作物の合計使用時間」とは, 当該ビ デオグラムに収録されている各著作物
の使用時間をそのまま合計し, 1 分未 満を切上げたものをいう。

（註 3 )「著作物の累計時間」とは, 当該ビデオ グラムに収録されている各著作物それ ぞれの使用時間の 1 分未満を切上げた うえ累計したものをいう。

（2）その他のビデオグラム

規定(1)による場合以外のビデオグラムに著作物を 使用する場合の著作物 1 曲の使用料は，次の基本使 用料と複製使用料を合計した額とする。

ただし，既に映画録音の許諾を得て製作され公表 されたものを複製するビデオグラムに著作物を使用 する場合は，複製使用料のみを適用する。

(1) 基本使用料 ビデオグラムの個数にかか わらず，当該著作物の使用 時間 1 分までごとに 800 円 とする。

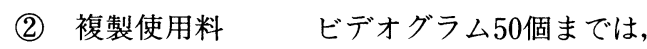
当該著作物の使用時間 1 分 までごとに 500 円とする。50 個をこえる場合は，こえる 1 個につき, 当該著作物の 使用時間 1 分までごとに 7 円とする。

2 演奏

ビデオグラムの演奏使用料については, 別に定め る。

（ビデオグラムの備考）

(1) テレビジョン放送で使用することを目的とし て製作されるビデオグラム，及びもっぱら映画 館等の施設において公に上映することを目的と して製作されるビデオグラム録音については， 第 4 節映画 1 録音の規定によるものとする。

(2) 1(1)の規定にかかわらず，劇場用映画を複製 するビデオグラムに著作物を使用する場合の使 用料は, 音楽を主体とするものを除き, 当該ビ 
デオグラムに使用される著作物の数及び使用時 間を問わず，当分の間，ビデオグラム 1 個につ き，当該ビデオグラムの小売価格（物品税を控 除したもの）に $\frac{1.75}{100}$ を乗じて得た額とする。

(3) 同一ビデオグラムにおいて同一著作物が断続 的又は繰り返し使用される場合の使用料は，そ の使用時間を合計して算出するものとする。

(4) 演劇的音楽著作物の全編又は当該ビデオグラ 么の全体を演劇的音楽著作物の要約又は抜粋で 構成する場合の使用料は，使用者と協議のうえ 定めることができる。

（5) 基本使用料について，著作物の性質その他特 別の事情により本規定により難しい場合は，使 用者と協議のうえこれと異る額を定めることが できる。

(6) 在外公館または海外事業所等の邦人に視聴さ せる目的で，テレビジョン放送番組を複製する ビデオグラムに著作物を使用する場合の使用料 は, 使用者と協議して定める額によることがで きる。

（7) 歌曲において楽曲に著作権がない場合，又は 本協会の管理外の場合の使用料は，1曲の使用 料の $\frac{6}{12}$ の額とする。

歌曲において歌詞が本協会の管理外の場合の 使用料は, 1 曲の使用料の $\frac{6}{12}$ の額とする。

Q 6 今度私の図書館では，利用者が求める資料をす ぐに検索できるように自館所蔵資料の文献デー夕 ベースを作成することになりました。その場合， 著作権法上どのようなことに注意する必要があり ますか。

A データベースに蓄積される情報は書誌事項や抄録 など多様なものがありますが，まずこれらの情報が 著作権法の保護対象であるかどうかを検討する必要 があります。

蓄積される情報として最初に考えられるのは, 所 蔵資料の題名, 著作者名, 揭載誌名, 発行者名等の 書誌事項です。これらのものは, 著作物とは考えら
れないので自由に利用することができます。

次に考之られるのは抄録ですが，抄録については 2 つの問題があります。1つは，既存の抄録誌など から該当する抄録を流用する場合です。抄録には大 きく分けて，原文献の内容を概括して記述する「報 知的抄録」と, 原文献の主題や範囲を記述するにと どまる「指示的抄録」の 2 通りがあるといわれてい ますが，いずれもその作成には相当の知的作業を必 要とするので，ほとんどの場合抄録は著作物である と考之られます。著作物を磁気ディスクや光ディス ク等の機械可読形式の媒体に蓄積することには著作 者の複製権 (21条) が㗢くので，この場合権利者の 許諾が必要です。もう 1 つの問題は, 自館で抄録を 作成する場合です。著作権法では，既存の著作物に 創作的な変更を加之て出来た著作物を二次的著作物 としこのような二次的著作物の作成行為について, 著作者の翻案権 (27条) が及ぶことにしています。 このことからデータベースに利用するため行う抄録 の作成が，原作者の翻訳権が及ぶ行為かどうかが問 題となりますが,一般的に，データベースに利用さ れる抄録は，内容の骨格をごく簡潔に示すにとどま ク，原文献で依存したものとはいえない場合が多い ので，原作者の翻案権は働かないと考えられます。

このほか, 数值デー夕自体は著作物でないので自 由には使えますが，それらを図表，グラフ等に加工 した場合，創作性があればその図表等は著作物にな ります。また，法令や判決文は著作物ではあるが著 作権法により著作権が否定されているので自由に使 えます。(13条)

なおこのような情報を蓄積して作成したデータ ベースは, 通常著作物であり著作権法の保護を受け ることになります。

Q 7 最近著作権法が改正され, コンピュータプログ ラムの著作権保護が明確化されたと聞きましたが その概要はどのようなものですか。

A コンピュータ・プログラムの保護の明確化をはか るための著作権法改正案は, 前の国会で成立し来年 
(昭和61年) の 1 月 1 日から施行されることになっ ています。

主な改正点は次のとおりです。

(1) プログラム保護の明確化(第 2 条, 第 10 条関係) プログラムが著作権法によって保護されることを 明確にするため, 著作物の例示に「プログラムの 著作物」を加えた。またこれに伴い，プログラム の定義規定を置いた。

(2) 法人著作の規定の整備（第15条関係）

現行法で法人等の使用者が著作者となるために は，(可法人等の発意に基づき，(价従業員が職務上 作成し, (门)当該法人等の名義で公表される著作物 であり，(工)作成時における契約, 勤務規則等に別 段の定めがないという 4 つの要件を満たすことが 必要である。

しかし, プログラムの場合, その多くは未公表 で利用されるものであり，また例えば ROM に固 定されて発売される等無名で公表される場合も多 い。

今回の法改正では，このようなプログラムの特 殊性に鑑み，プログラムに関する限りの特例とし て，上記(ウ)の要件を必要とせず(ア)，(イ)及び(エ)の要 件を満たせば法人著作を認めることとした。

(3) 同一性保持権の適用の制限（第20条関係）

著作権法では著作者人格権の 1 つである同一性 保持権すなわち著作者の意に反してその著作物及 びその題号を改変されない権利を定めている。

プログラムの場合，その利用に当たっては，バ グの修正, プログラムの効率性の向上のための バージョンアップ等による修正, 增減が行われる のが通常であり，しかもこれにより著作者の名誉， 声望が害されるとは考えられないので，このよう な改変については同一性保持権が及ばない旨の規 定を新設した。

(4) プログラムの著作物の複製物の所有者による複 製等（第47条の 2 関係）

プログラムの利用に当たっては，プログラムの 滅失, 毁損等に備えるため予備の複製物を作成す ること, 磁気テープから磁気ディスクに記憶媒体
を変更すること, 既存のプログラムに新たな機能 を付加することなど複製又は翻案を伴う利用が通 常行われる。

このようなことから今回の改正では，プログラ ムの著作物の複製物の所有者が行う自己利用のた めに必要な複製, 翻案を必要と認められる限度に おいて行うことができる旨の規定を新設した。

(5) 創作年月日の登録制度の新設等（第76条の 2 , 第78条の 2 関係)

現行法では, (予実名の登録 (75条), (亿)第 1 発行 年月日等の登録 $(76$ 条) 及び(ウ)著作権の登録（権 利の移転等があった場合の対抗要件, 77条) の 3 種の登録が認められている。

プログラムについても,この要件を満たせば(ア), (イ)及び(ウの登録を受けることができるが，プログ ラムは未公表で使用されることが多いので，実質 的に現行法では著作物の公表を前提とする(ア)及び (イ)の登録ができないことになる。

このようなことから, 今回の改正では, プログ ラムについても権利保全を十分に図ることができ るように，新たに創作年月日の登録を新設した。 具体的には，プログラムの著作物の著作者は，公 表，未公表を問わず，その著作物の創作後 6 ケ月 以内に登録を受けることができ，その登録に係る 年月日において創作があったものと推定される。

なお，登録手続等については別の法律で定める ことにしており，その法律が施行されるまでこの 登録制度は発効しない。

６）海賊盤プログラムの使用の規制（第113条関係） プログラムの場合，それを電子計算機で使用す ることにより，大きな経済的利益を得ることがで きるという特性がある。

この点から, プログラムを十分に保護するため, プログラムの複製物の使用の権限を取得した時点

（購入等）で，その複製物が違法に作成されたも のであることを知って業務上電子計算機において 使用する行為を著作権侵害とみなす旨の規定を新 設した。 


\section{参 考 文 献}

1) 文化庁編：著作権法ハンドブック, 東京, 著作権 資料協会, 1985 .

2 ）加戸守行：著作権法逐条講義, 東京, 著作権資料 協会, 1979 .

3 ）著作権審議会第 4 小委員会（複写複製関係）報告 書, 東京, 文化庁, 1976 .
4 ) 著作権審議会第 7 小委員会（ニューメディア及び データベース関係) データベース分科会中間報告, 東京, 文化庁, 1984 .

5 ) 文化庁著作権課：著作権法の一部改正（コン ピュータ・プログラム関係）について，文化庁月 報, No. 201, 10-13, 1985.

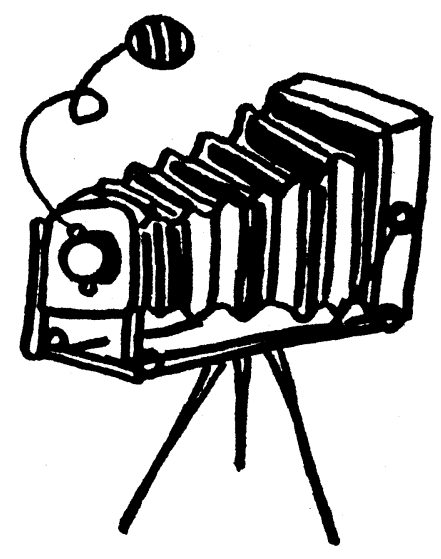

